\title{
A Research of Applicability of Ozone Bleaching Process for $100 \%$ Cotton Fabrics at Jigger Machine
}

\author{
Navruz Paksoy ${ }^{1}$, Onur Balcı ${ }^{1}$, Burcu Sancar Beşen ${ }^{2}$ \\ ${ }^{1}$ Kahramanmaraş Sütçü İmam University, Faculty of Engineering and Architecture, Department of Textile Engineering, Avşar Campus, \\ Kahramanmaraş \\ ${ }^{2}$ Adıyaman University, Faculty of Engineering, Department of Textile Engineering, Adıyaman/Turkey
}

Corresponding Author: : Navruz PAKSOY, nevruzpaksoy_@hotmail.com

\begin{abstract}
In the present study, applicability of ozone bleaching process at the jigger machine and effects of chosen ozonation parameters on the whiteness degrees of $100 \%$ cotton woven fabrics were investigated. For this aim, effects of ozone gas on the bleaching degrees of the samples in terms of ozonation conditions (in the air with dry and moist fabrics, and in the water), ozonation time (number of the passage), production capacity of the ozone generator $(6 \mathrm{~g} / \mathrm{h}, 12 \mathrm{~g} / \mathrm{h}, 18 \mathrm{~g} / \mathrm{h})$ and method of ozone feeding to the jigger (via rubber diffuser or stone diffuser) were researched. In addition, in order to examine effect of rinsing process on the whiteness degree of the samples, the rinsing process was applied after ozonation applications. At the end of the study, whiteness degrees (as Berger) of the samples were measured and compared with conventional hydrogen peroxide bleaching. In addition, statistical analysis was carried out in order to research the effects of the investigated parameters on the output. The results showed that it was possible to apply the ozone bleaching process at the jigger and all of the investigated ozonation parameters had effect on the results at different levels. The best bleaching effect was obtained at the longest ozonation time and the highest production capacity of the ozone generator for ozone application in the water.
\end{abstract}

\author{
ARTICLE HISTORY \\ Received: 28.05.2019 \\ Accepted: 25.06.2020
}

\section{KEYWORDS}

Ozone, Bleaching, Jigger machine, Whiteness, Rinsing

\section{INTRODUCTION}

Recently, every branch of industry has taken precautions in order to use the nature sources more beneficial and go towards to the clean technologies due to the problems of environmental pollution, limited water sources, and wasting of energy, etc. [1-3]. Textile industry is a water intensive industry which causes big problem on the global water resource. The increasing concern about the textile wet processing industry is arisen from high water consumption, huge amount of wastewater discharge and high pollution potential [3-5].

The environmental impacts of the textile industry can be substantially reduced via using advanced techniques and technologies, which help to decrease wasting of energy and water, and cut emissions [6,7]. Through the advanced technologies, ozone application has had high popularity for many years $[2,8,9]$.

Ozone has the most extremely strong oxidizing character known after the fluorine [2,5,10-13,21-23]. It can participate in many chemical reactions with inorganic and organic substances because of strong oxidizing property $[7,12,23]$. Besides, it self-decomposed in an aqueous solution to form hydroxyl free radicals which have stronger oxidizing ability. Therefore, ozone has been widely accepted as a forceful disinfectant and a chemical oxidant [14-17,21]. It has been used as an eco-friendly alternative process in order to prevent environmental pollution in many

To cite this article: Paksoy N, Balcı O, Sancar Beşen B. 2020. A research of applicability of ozone bleaching process for $100 \%$ cotton fabrics at jigger machine. Tekstil ve Konfeksiyon, 30(3), 173-183. 
branch of industry such as food, agriculture, textile, automotive, etc., because it can readily decay to oxygen after treatments $[7,18]$.

Ozone gas having decolorization property $[2,19]$ has been commonly used at the bleaching process of the cellulosic fabrics as an eco-friendly agent [4,7,9,12,13,24,25] since bleaching of cellulosic fabrics with hydrogen peroxide is required high alkali $\mathrm{pH}$, high temperature and some auxiliaries $[25,26]$. Cotton fabrics can be bleached with ozone in very short time at the room temperature, and without using any harsh chemicals [26]. Besides, according to researchers, cotton fabric uses less water when ozone is employed for bleaching agent [7,25,26]. In addition, Harreem et.al (2019) concluded that it was possible to reuse the effluent of ozone bleaching bathat least five times with no treatment or adjustment required, and it did not affect the fabric whiteness and discharged effluent which is cleaner compared to the hydrogen peroxide bleaching [26].

When the literature was investigated in detail, it was concluded that the bleaching effect of the textile surfaces changed depending on the ozone concentration, ozonation time, moisture content of the sample, application way of the ozone gas to the samples, etc. [20]. In the present study, usability of the ozone gas at the jigger machine as bleaching material that could be defined as a novel wet process and effects of the ozonation parameters on the whiteness degrees of $100 \%$ cotton woven fabrics were investigated. For this aim, the effects of the ozone gas on the bleaching degrees of the fabric samples in terms of the ozonation condition (in the air and in the water), ozonation time, production capacity of the ozone generator and method of ozone feeding to the jigger were researched.

\section{MATERIAL AND METHOD}

\subsection{Material}

In the study, amylase enzyme (Rucolase HPZ, Rudolf Duraner), pectinase enzyme (Rucolase PTZ, Rudolf Duraner), catalase enzyme (Rucolase CAP, Rudolf Duraner), hydrogen peroxide (Tekkim Chemistry), sodium carbonate (Tekkim Chemistry), wetting agent (Rucowet
RKB, Rudolf Duraner), sodium hydroxide (Tekkim Chemistry), organic stabilizer (Ruco-Stab OKM, Rudolf Duraner) were used.100\% cotton woven fabric (weft: Ne 30/1 compact, warp: Ne 30/1 ring yarn, 3/1 S twill, 167 $\mathrm{g} / \mathrm{m}^{2}$ ) having starch sizing on the warp yarns was also used for experiments.

In the ozone applications, ozone generators having capacity of $6 \mathrm{~g} / \mathrm{h}$ and $12 \mathrm{~g} / \mathrm{h}$ were used. $18 \mathrm{~g} / \mathrm{h}$ ozone capacity was also obtained by connecting in series of two ozone generators' outputs. The applications were carried out at the laboratory type jigger machine (ATAÇ) of which technical drawing was given in Figure 1.

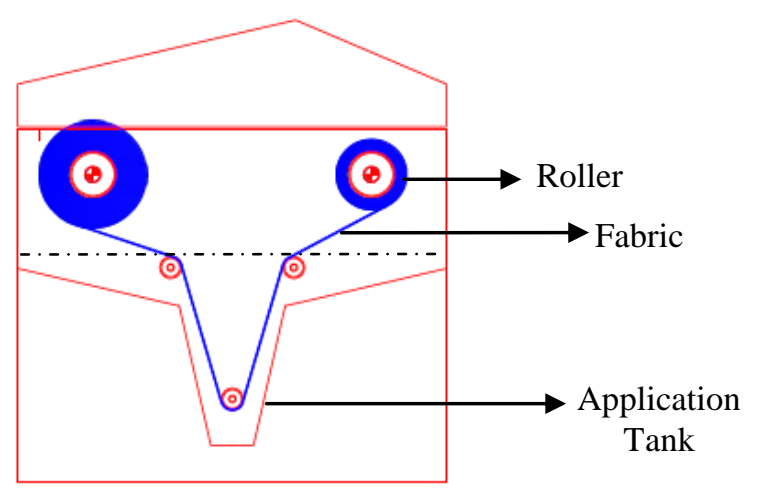

Figure 1. The technical drawing of the jigger machine [20]

Two different diffusers which were rubber $(\mathrm{RD}$, material: rubber + plastic; outlet diameter*inner diameter $0.35 * 0.27$ $\mathrm{cm}$ ) and stone (SD, material: mineral+plastic; outlet connector diameter: $6 \mathrm{~mm} / 0.24 \mathrm{inch}$; stone length: $20 \mathrm{~cm} / 8$ inch)were placed in the jigger machine in order to transfer the ozone gas to the inner of the machine. Although the rubber diffusor was not compatible for ozone gas, it was used in order to examine the results. In this sense, it regularly deformed, the deformation was followed and it was changed with new one in a way that does not affect the results. The rubber diffuser was placed at the bottom of the application tank (under the drive roller) while the stone one was placed out of the tank (Figure 2). The ozone gas was directly applied to the samples in the machine.

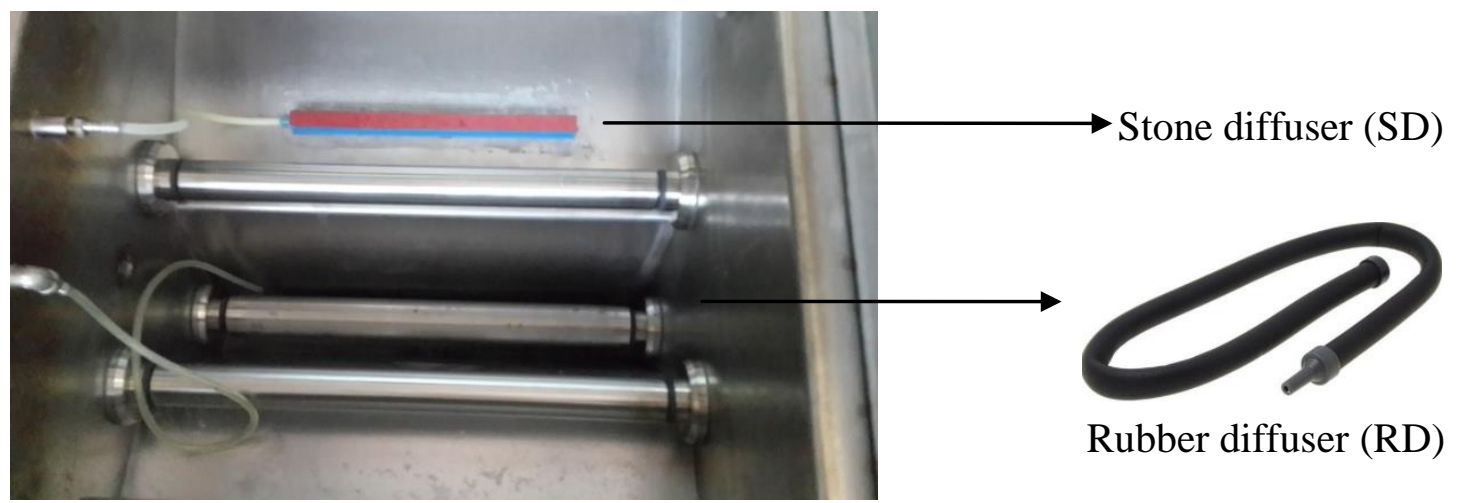

Figure 2. The settlement of the diffusers transferring the ozone gas [20] 


\subsection{Method}

\subsubsection{Desizing and bioscouring processes}

The fabric samples were prepared to ozone applications by desizing and bioscourig processes which were applied simultaneously. The process was carried out by using $1 \mathrm{~g} / \mathrm{l}$ amylase, $3 \mathrm{~g} / 1$ pectinase and $2 \mathrm{~g} / 1$ wetting agent at $60^{\circ} \mathrm{C}$ during 30 minutes ( $\mathrm{pH} 8-8.5$ with sodium carbonate). After the process, the fabric was rinsed with hot water (at $90^{\circ} \mathrm{C}$ ) during 20 minutes.

\subsubsection{Conventional bleaching process}

In order to compare the ozone with the conventional applications, hydrogen peroxide bleaching was also carried out in the jigger machine. The bleaching was applied by using $3 \mathrm{~g} / 1 \mathrm{H}_{2} \mathrm{O}_{2}, 2 \mathrm{~g} / \mathrm{l} \mathrm{NaOH}, 1 \mathrm{~g} / \mathrm{l}$ wetting agent and 0.5 $\mathrm{g} / \mathrm{l}$ stabilizer at $90^{\circ} \mathrm{C}$ during an hour. After bleaching, 0.2 $\mathrm{g} / 1$ catalase enzyme ( $\mathrm{pH}$ 6-6.5) was applied to the fabric at $50{ }^{\circ} \mathrm{C}$ during 15 minutes.

\subsubsection{Ozone bleaching process}

Ozone bleaching processes were applied to pretreated fabric samples at the different ozonation conditions (in the air with dry and moist fabrics, and in the water), ozonation time (number of passage), production capacity of the ozone generator and method of ozone feeding. Ozone applications in the water (at $\mathrm{pH}$ 6-6.5) were carried out in the waterfilled jigger application tank. Besides, applications in the air were applied at two conditions as moist and dry fabrics. In order to obtain moist fabrics, dry fabrics were immersed into the water (at $\mathrm{pH}$ 6.5)in the jigger and squeezed directly up to $60 \%$ pick up. After those applications, the samples had limited water and defined as moist fabrics. In addition, applications in the air were repeated with dry fabrics which were not contacted any solutions.

The ozone gas produced by two different generators was transferred to the diffusers by different eight methods as shown in Figure 3 and Table 1.

(a)

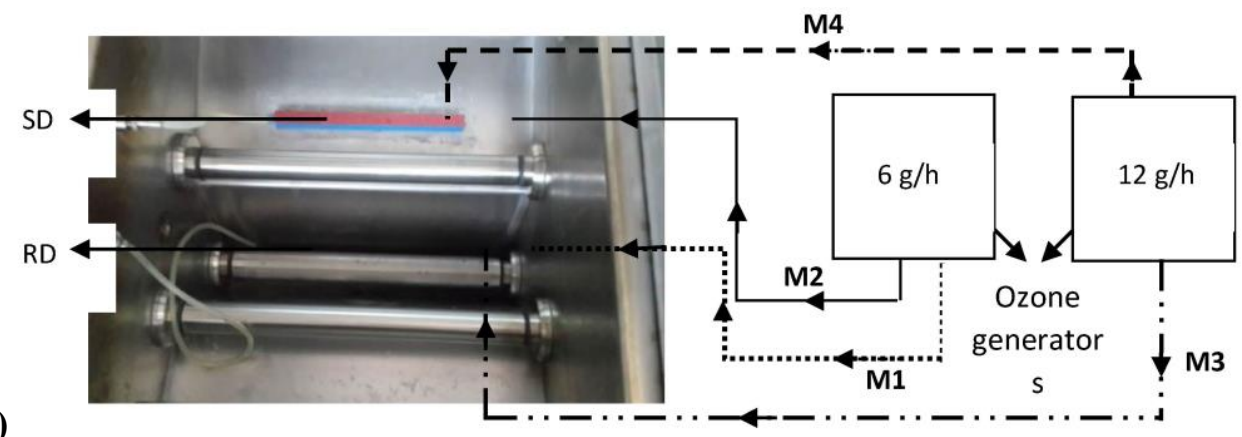

(b)

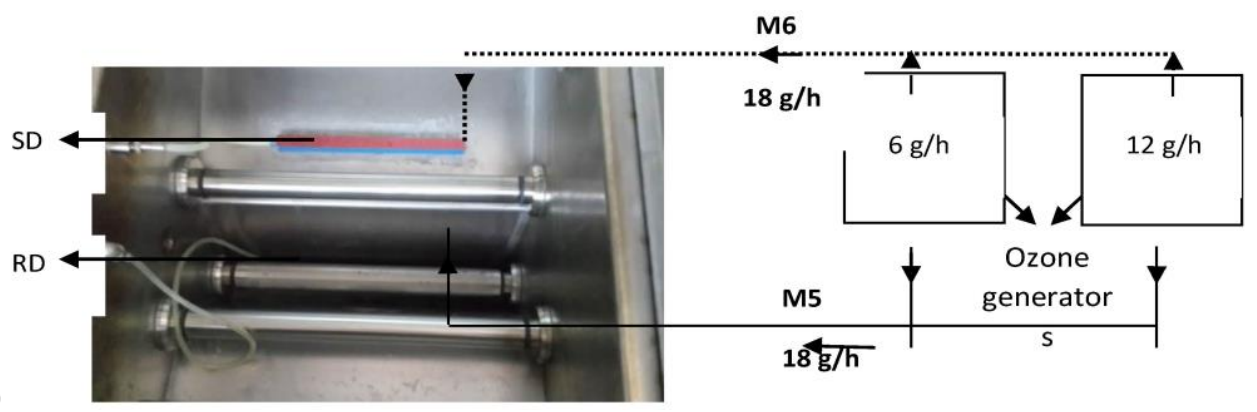

(c)

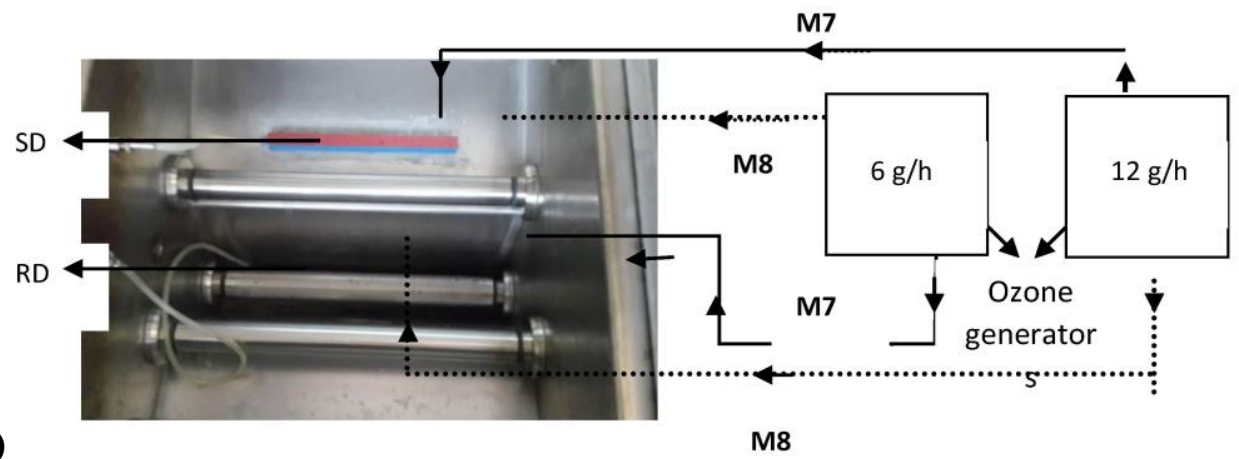

Figure 3. The methods of the ozone feeding to the jigger 
Table 1. The methods of the ozone feeding to the jigger

\begin{tabular}{cc}
\hline Method & $\begin{array}{c}\text { The capacity of the ozone generator-The } \\
\text { diffuser used in the transfer }\end{array}$ \\
\hline M1 & $6 \mathrm{~g} / \mathrm{h}-\mathrm{RD}$ \\
M2 & $6 \mathrm{~g} / \mathrm{h}-\mathrm{SD}$ \\
M3 & $12 \mathrm{~g} / \mathrm{h}-\mathrm{RD}$ \\
M4 & $12 \mathrm{~g} / \mathrm{h}-\mathrm{SD}$ \\
M5 & $18 \mathrm{~g} / \mathrm{h}-\mathrm{RD}$ \\
M6 & $18 \mathrm{~g} / \mathrm{h}-\mathrm{SD}$ \\
M7 & $6 \mathrm{~g} / \mathrm{h}-\mathrm{RD}+12 \mathrm{~g} / \mathrm{h}-\mathrm{SD}$ \\
M8 & $12 \mathrm{~g} / \mathrm{h}-\mathrm{RD}+6 \mathrm{~g} / \mathrm{h}-\mathrm{SD}$ \\
\hline
\end{tabular}

As seen in Figure 3and Table 1, produced ozone gas having capacities of $6 \mathrm{~g} / \mathrm{h}, 12 \mathrm{~g} / \mathrm{h}$ and $18 \mathrm{~g} / \mathrm{h}$ was transferred to the jigger via either stone diffuser or rubber diffuser (M1-M6) since the diffuser type had crucial effect on the solubility of the ozone in the water. In addition, the ozone applications with the capacity of $18 \mathrm{~g} / \mathrm{h}$ were applied by using both stone diffuser and rubber diffuser, together. In those applications, two ozone generators were not connected in series and ozone gas produced by the ozone generators (capacity of $6 \mathrm{~g} / \mathrm{h}$ and $12 \mathrm{~g} / \mathrm{h}$ ) was transferred via two different diffusers, separately (M7 and M8). Thus, there was obtained totally ozone capacity of $18 \mathrm{~g} / \mathrm{h}$ in the jigger machine. Besides, in the study, the application time was also wanted to be researched and different eight passage number was chosen as other variable.

All of the experiments were carried out at the room temperature (ca. $25^{\circ} \mathrm{C}$ ). Experimental plan of the ozone bleaching was given in Table 2.

The study about the rinsing process after ozone bleaching showed that the rinsing process had had positive effect on the whiteness degree of the samples [13]. Based on that study, in the present study, the whiteness degrees of the fabric samples were also investigated before and after the rinsing processes.
The whiteness degrees of the fabric samples after bleaching processes were measured as Berger value under D65 daylight and 10 degrees viewing angle via Minolta $3600 \mathrm{~A}$ spectrophotometer. Whole measurements were carried out for three times from different locations of the fabric samples (thus, the whiteness homogeneity of the fabrics was also examined) and average of the results was calculated. At the end of the study, the statistical analysis was performed using the results of the whiteness degrees of the fabric samples in order to determine the effect of the investigated working parameters (input) on the results (output) by one-way ANOVA via Design Expert 7.0 Trial Version. The results were evaluated at $5 \%$ significance level. While the ANOVA results were being made, it was focused on $F$ and $p$ values. While the significance contribution of the investigated factors on the variance increases, $F$ and $p$ values increase and decrease, respectively. In particular, $p$ values must be less than 0.05 in order to define a factor as statistically significant.

\section{RESULTS}

\subsection{The whiteness results}

After the ozone applications, Berger values of the fabric samples before and after rinsing process were measured and given via graphs. In the graphs, experimental number 1 described desizing and bioscouring process while the experimental number 2 defined conventional bleaching process (reference bleaching).

Berger results of the ozone applications in the water were given in Figure 4-7.

Table2. Experimental plan of the ozone bleaching [20]

\begin{tabular}{|c|c|c|c|c|}
\hline $\begin{array}{l}\text { Exp. number } \\
\text { (in the water)-A }\end{array}$ & $\begin{array}{c}\text { Exp. number } \\
\text { (in the air-moist)-B }\end{array}$ & $\begin{array}{c}\text { Exp. number } \\
\text { (in the air-dry)-C }\end{array}$ & $\begin{array}{l}\text { Passage } \\
\text { Number }\end{array}$ & $\begin{array}{l}\text { Method of ozone } \\
\text { feeding (Table 1) }\end{array}$ \\
\hline $\begin{array}{c}\text { 1A-9A-17A-25A-33A- } \\
\text { 41A-49A-57A }\end{array}$ & $\begin{array}{c}\text { 1B-9B-17B-25B-33B- } \\
\text { 41B-49B-57B }\end{array}$ & $\begin{array}{c}\text { 1C-9C-17C-25C-33C- } \\
41 \mathrm{C}-49 \mathrm{C}-57 \mathrm{C}\end{array}$ & 50 & $\begin{array}{c}\text { M1-M2-M3-M4-M5- } \\
\text { M6-M7-M8 }\end{array}$ \\
\hline $\begin{array}{c}\text { 2A-10A-18A-26A-34A- } \\
\text { 42A-50A-58A }\end{array}$ & $\begin{array}{c}\text { 2B-10B-18B-26B-34B- } \\
\mathbf{4 2 B}-50 \mathrm{~B}-\mathbf{5 8 B}\end{array}$ & $\begin{array}{c}2 \mathrm{C}-10 \mathrm{C}-18 \mathrm{C}-26 \mathrm{C}-34 \mathrm{C}- \\
\mathbf{4 2 C}-50 \mathrm{C}-58 \mathrm{C}\end{array}$ & 60 & $\begin{array}{l}\text { M1-M2-M3-M4-M5- } \\
\text { M6-M7-M8 }\end{array}$ \\
\hline $\begin{array}{c}\text { 3A-11A-19A-27A-35A- } \\
\text { 43A-51A-59A }\end{array}$ & $\begin{array}{c}\text { 3B-11B-19B-27B-35B- } \\
\text { 43B-51B-59B }\end{array}$ & $\begin{array}{c}\text { 3C-11C-19C-27C-35C- } \\
\text { 43C-51C-59C }\end{array}$ & 70 & $\begin{array}{l}\text { M1-M2-M3-M4-M5- } \\
\text { M6-M7-M8 }\end{array}$ \\
\hline $\begin{array}{c}\text { 4A-12A-20A-28A-36A- } \\
\text { 44A-52A-60A }\end{array}$ & $\begin{array}{c}\text { 4B-12B-20B-28B-36B- } \\
\text { 44B-52B-60B }\end{array}$ & $\begin{array}{c}4 \mathrm{C}-12 \mathrm{C}-20 \mathrm{C}-28 \mathrm{C}-36 \mathrm{C}- \\
\text { 44C-52C-60C }\end{array}$ & 80 & $\begin{array}{l}\text { M1-M2-M3-M4-M5- } \\
\text { M6-M7-M8 }\end{array}$ \\
\hline $\begin{array}{c}\text { 5A-13A-21A-29A-37A- } \\
\text { 45A-53A-61A }\end{array}$ & $\begin{array}{c}\text { 5B-13B-21B-29B-37B- } \\
\text { 45B-53B-61B }\end{array}$ & $\begin{array}{c}\text { 5C-13C-21C-29C-37C- } \\
\text { 45C-53C-61C }\end{array}$ & 90 & $\begin{array}{l}\text { M1-M2-M3-M4-M5- } \\
\text { M6-M7-M8 }\end{array}$ \\
\hline $\begin{array}{c}\text { 6A-14A-22A-30A-38A- } \\
\text { 46A-54A-62A }\end{array}$ & $\begin{array}{c}\text { 6B-14B-22B-30B-38B- } \\
\text { 46B-54B-62B }\end{array}$ & $\begin{array}{c}\text { 6C-14C-22C-30C-38C- } \\
\text { 46C-54C-62C }\end{array}$ & 100 & $\begin{array}{l}\text { M1-M2-M3-M4-M5- } \\
\text { M6-M7-M8 }\end{array}$ \\
\hline $\begin{array}{c}\text { 7A-15A-23A-31A-39A- } \\
\text { 47A-55A-63A }\end{array}$ & $\begin{array}{c}\text { 7B-15B-23B-31B-39B- } \\
\text { 47B-55B-63B }\end{array}$ & $\begin{array}{c}\text { 7C-15C-23C-31C-39C- } \\
\text { 47C-55C-63C }\end{array}$ & 110 & $\begin{array}{l}\text { M1-M2-M3-M4-M5- } \\
\text { M6-M7-M8 }\end{array}$ \\
\hline $\begin{array}{c}\text { 8A-16A-24A-32A-40A- } \\
\text { 48A-56A-64A }\end{array}$ & $\begin{array}{c}\text { 8B-16B-24B-32B-40B- } \\
\text { 48B-56B-64B }\end{array}$ & $\begin{array}{c}\text { 8C-16C-24C-32C-40C- } \\
\text { 48C-56C-64C }\end{array}$ & 120 & $\begin{array}{l}\text { M1-M2-M3-M4-M5- } \\
\text { M6-M7-M8 }\end{array}$ \\
\hline
\end{tabular}




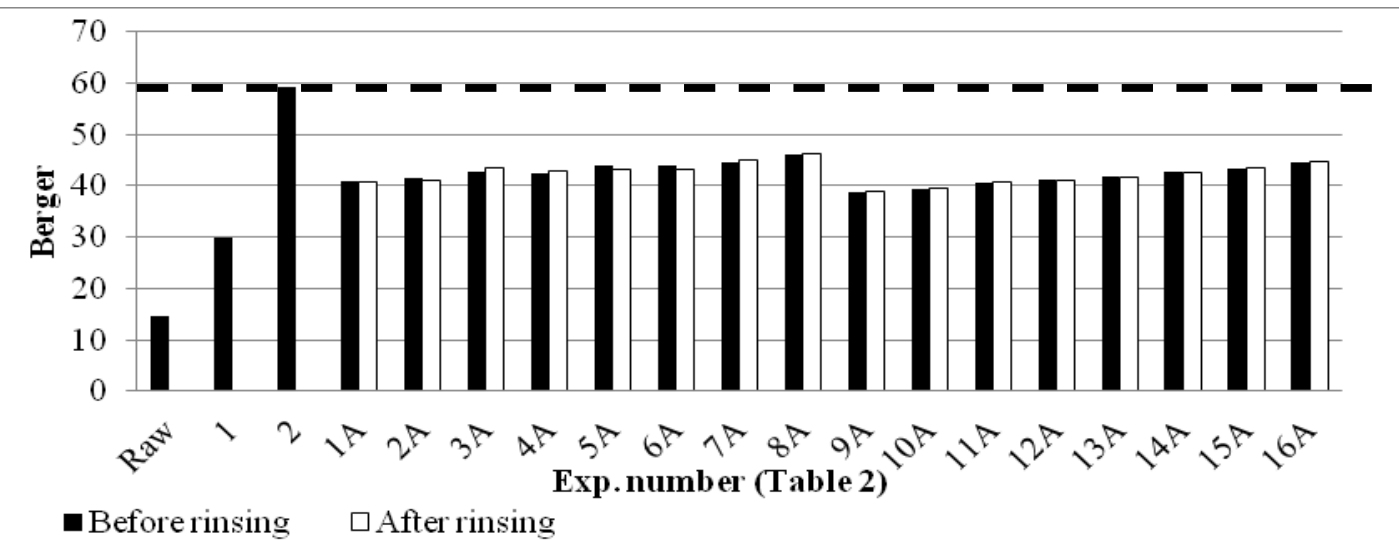

Figure 4. Berger results of the ozone applications in the water with M1 and M2

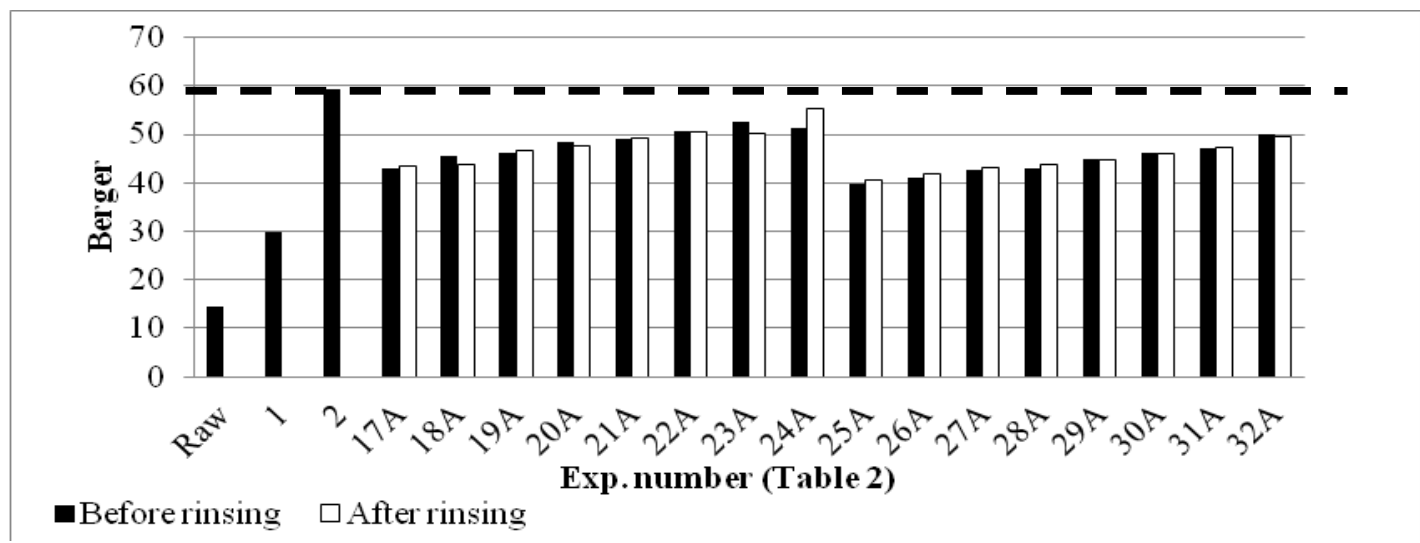

Figure 5. Berger results of the ozone applications in the water with M3 and M4

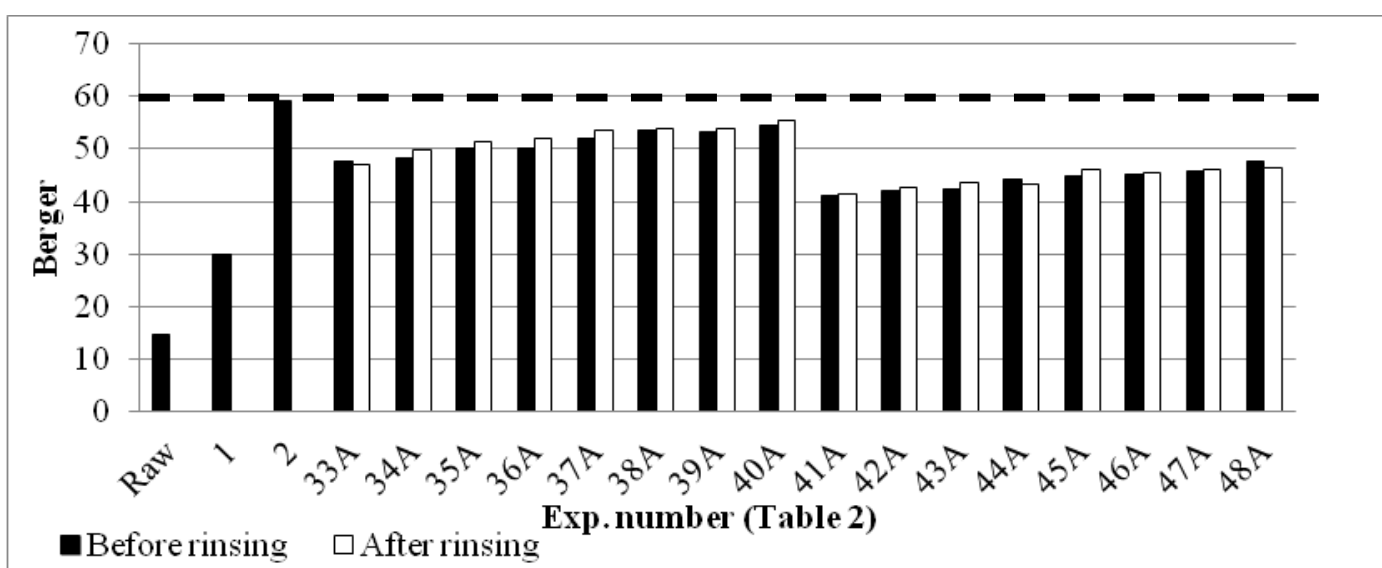

Figure 6. Berger results of the ozone applications in the water with M5 and M6

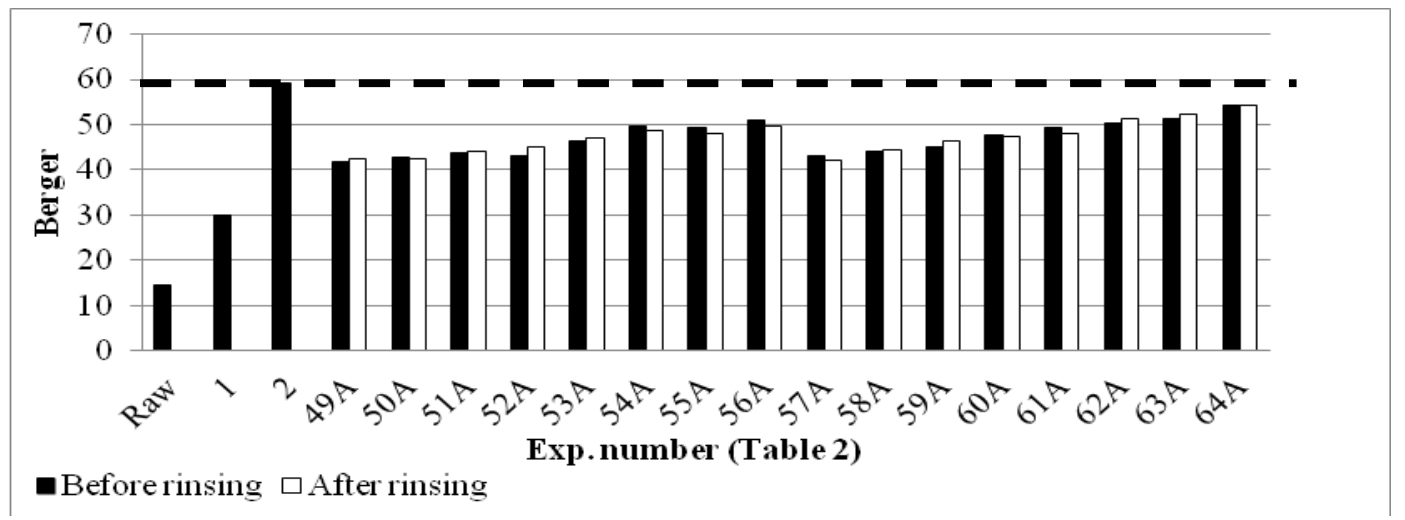

Figure 7. Berger results of the ozone applications in the water with M7 and M8 
When Figure 4-7 were investigated, it was clearly seen that Berger value of reference bleaching was 59.27 and higher than all of the ozone applications in the water. Increments at the ozonation time (number of passage) and production capacity of the ozone gas were approached Berger values of the samples to the reference bleaching. When the applications of 50 passage and 120 passage were compared, almost $20 \%$ improvement at the whiteness was achieved depending on the capacity and method of the feeding of the ozone gas. In all applications, the method of feeding of the ozone gas affected the results because itchanged the solubility of the ozone gas, and the size and homogeneity of the ozone bubbles. Generally, Berger values of the applications with rubber diffuser were higher than stone one. While the highest Berger value was obtained as 55.48 with rubber diffuser, it was 49.88 with stone diffuser. It was thought to be concluded from position of the diffusers. The rubber diffuser was placed at the bottom of the application tank while the stone one was placed out of the tank. For this reason, there were more ozone bubbles that dissolved in the water while working with rubber diffusor. In addition, rinsing process had not crucial effect on the results. When the results of applications with different combinations of the ozone capacity of $6 \mathrm{~g} / \mathrm{h}$ and $12 \mathrm{~g} / \mathrm{h}$ (Figure 8 and Figure 9) were investigated, it was possible to say that Berger results of the applications with the ozone capacity of $18 \mathrm{~g} / \mathrm{h}$ by using single diffuser was higher.

Berger results of the ozone applications in the air to the moist fabric samples were given in Figure 8-11.

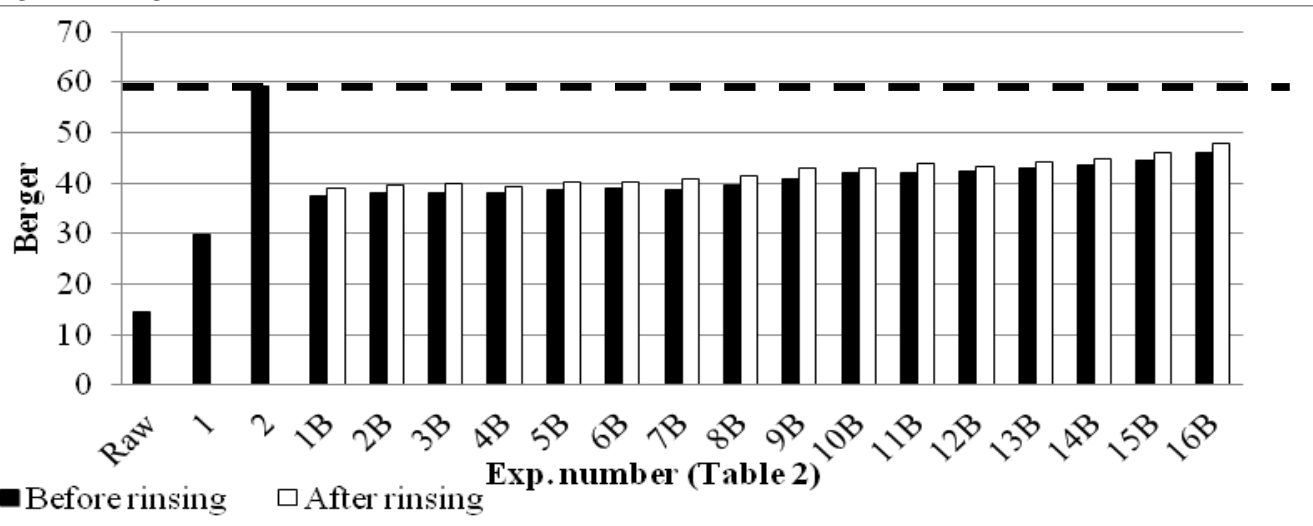

Figure 8. Berger results of the ozone applications in the air to the moist samples with M1 and M2

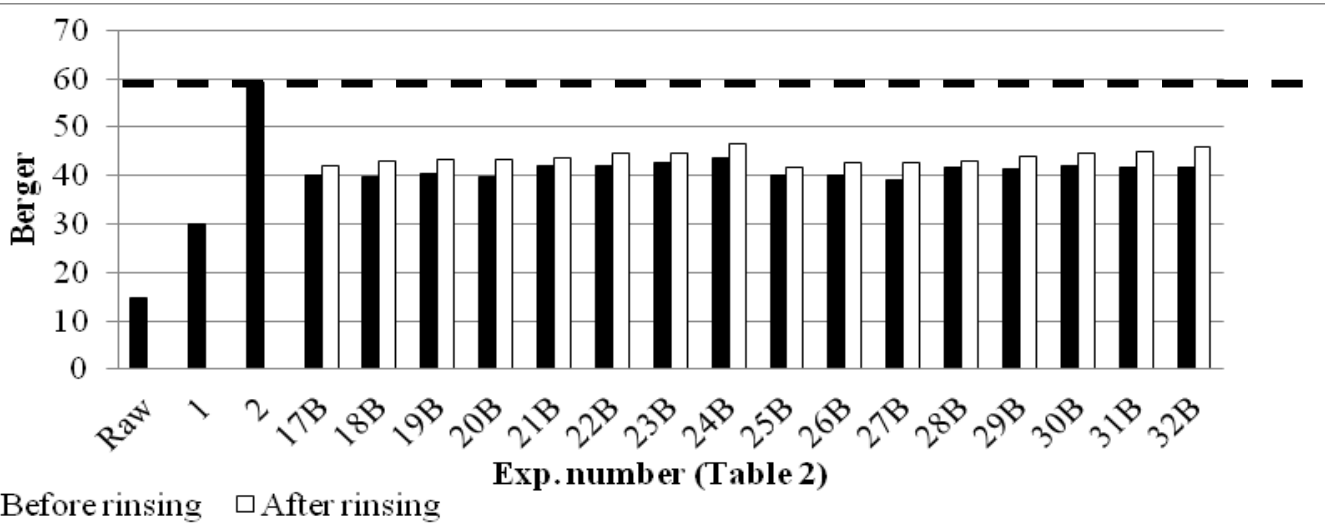

Figure 9. Berger results of the ozone applications in the air to the moist samples with M3 and M4

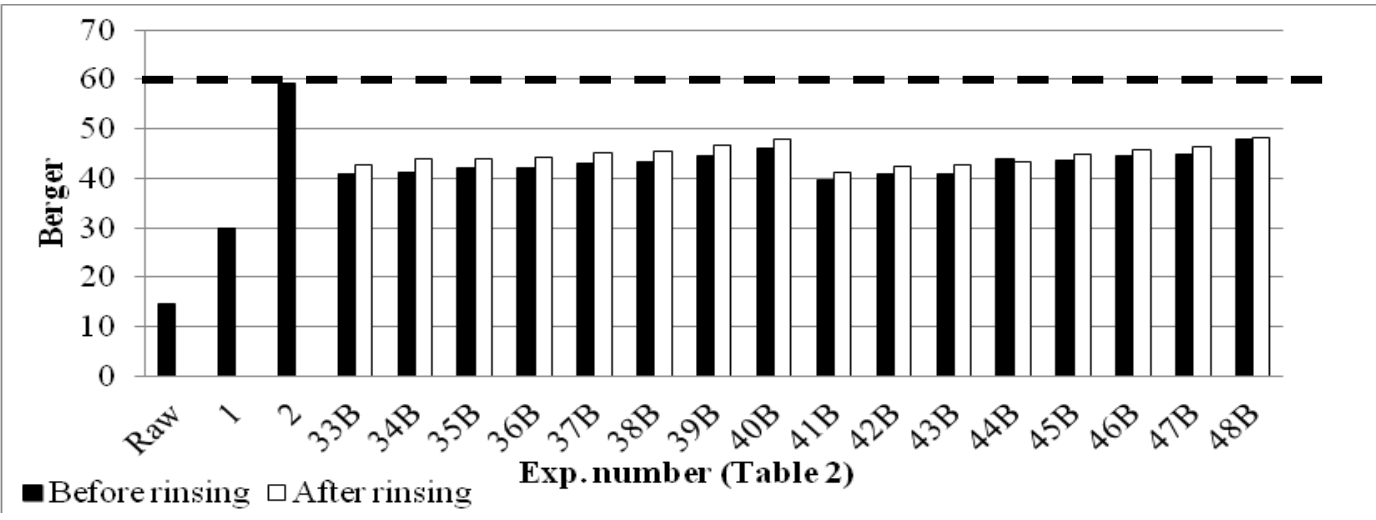

Figure 10. Berger results of the ozone applications in the air to the moist samples with M5 and M6 


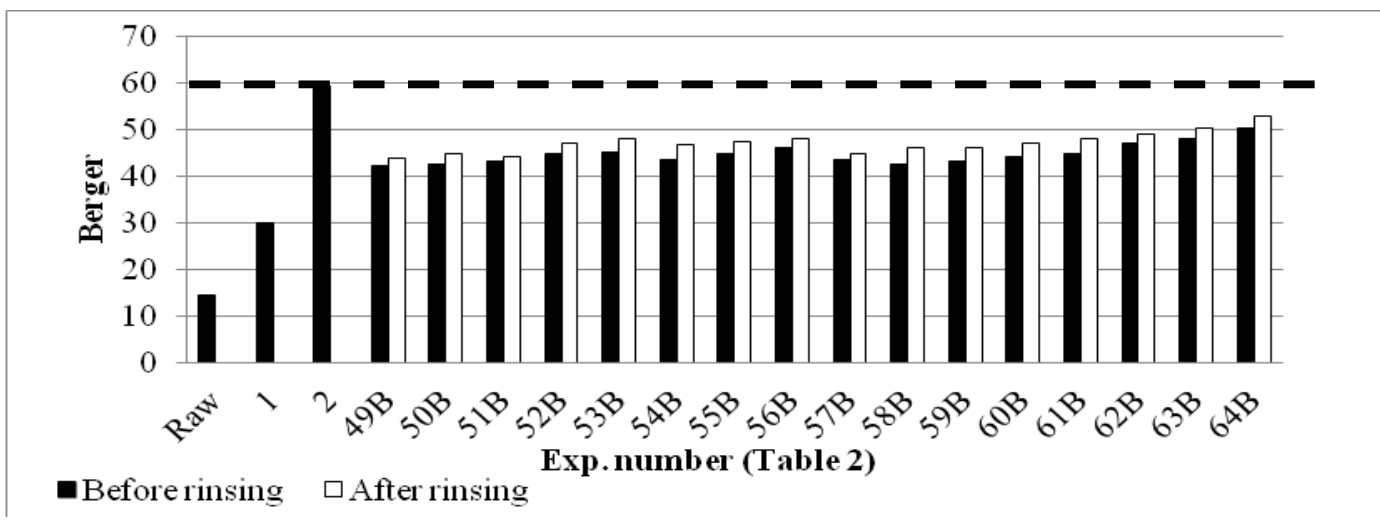

Figure 11. Berger results of the ozone applications in the air to the moist samples with M7 and M8

Figure 8-11 showed that Berger value of reference bleaching was higher than the ozone applications in the air to the moist samples. Similar with the applications in the water, increment in the number of passage and ozone capacity enhanced the whiteness degrees. Generally, Berger results of the moist ozone applications remained lower than in water ones. In those applications, the highest whiteness degree was obtained as 52.75 Berger and rinsing process had positive effect on the whiteness of the samples. In addition, there were not crucial whiteness differences between usage of the rubber diffuser and stone diffuser. It was possible to say that since there was not solubility situation of the ozone gas in the water for the applications in the air, the way of ozone feeding to the medium was not important.

Berger results of the ozone applications in the air to the dry fabric samples were given in Figure 12-15.

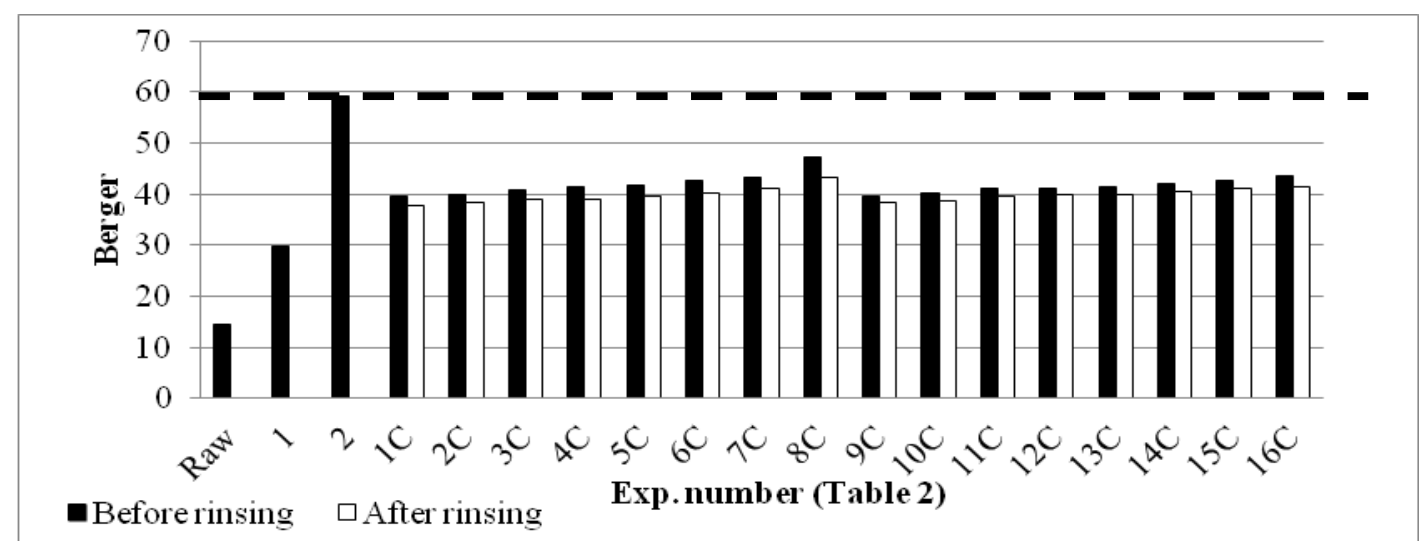

Figure 12. Berger results of the ozone applications in the air to the dry fabric samples with M1 and M2

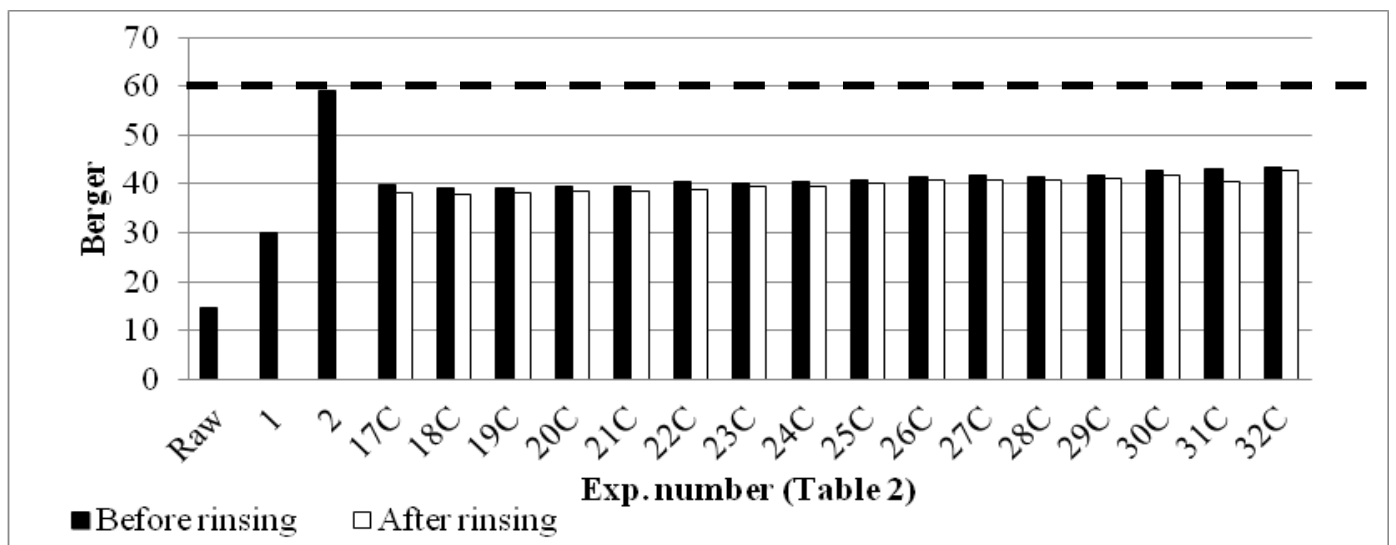

Figure 13. Berger results of the ozone applications in the air to the dry fabric samples with M3 and M4 


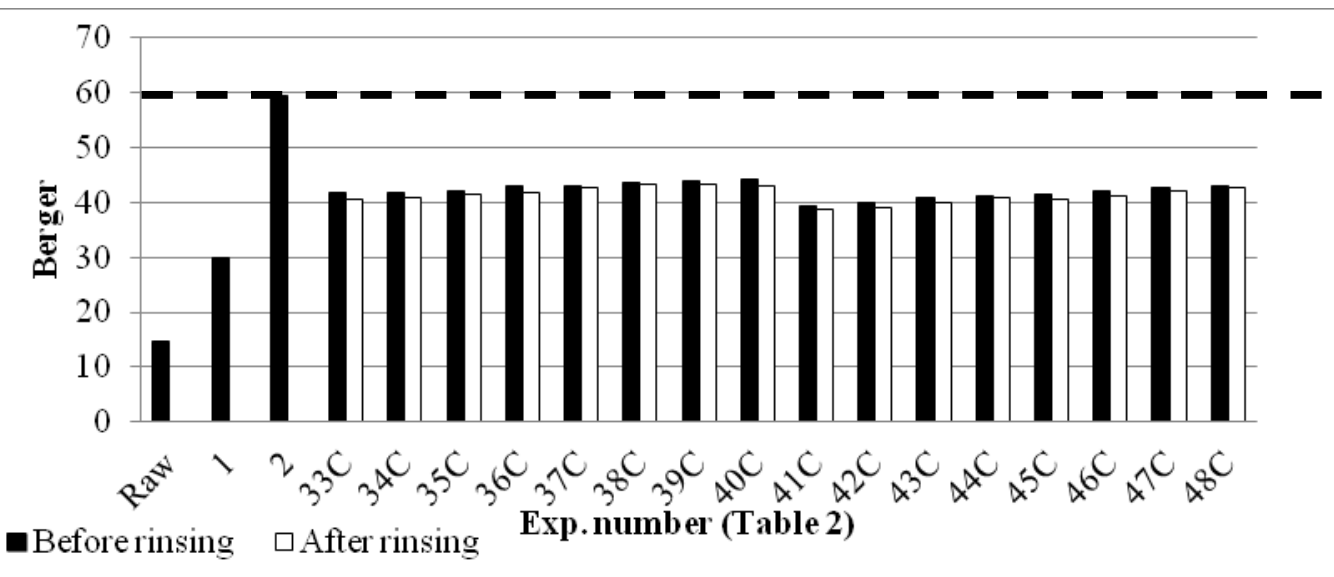

Figure 14. Berger results of the ozone applications in the air to the dry fabric samples with M5 and M6

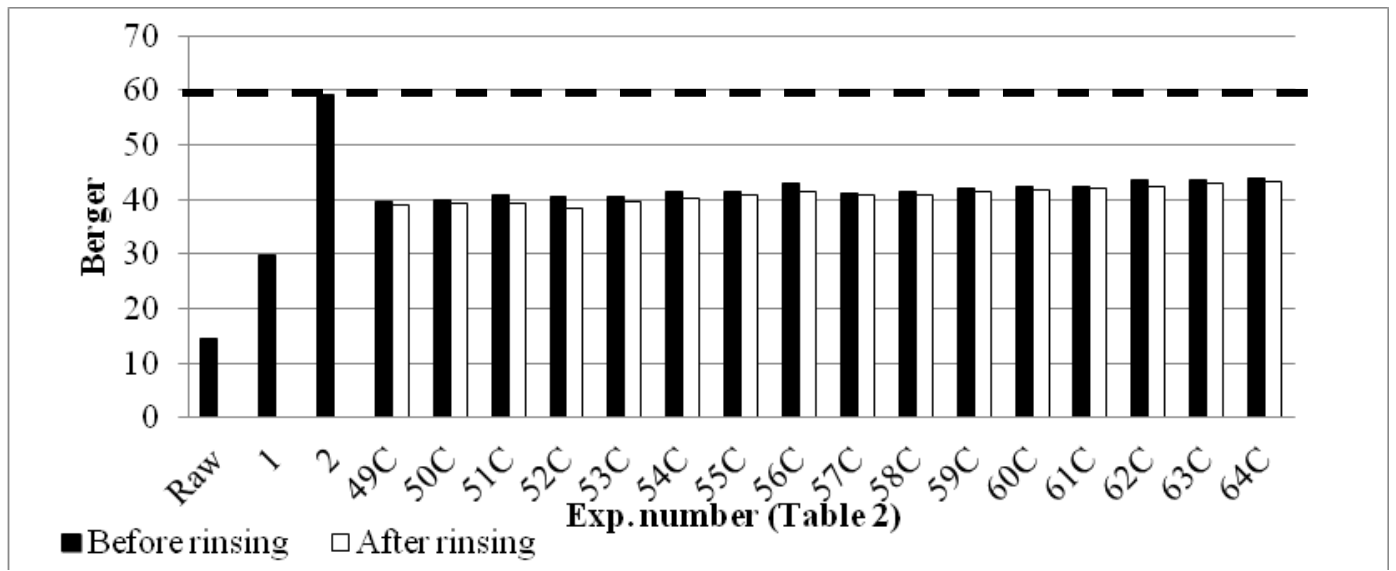

Figure 15. Berger results of the ozone applications in the air to the dry fabric samples with M7 and M8

As seen in Figure 12-15, Berger results of the ozone applications in the air to the dry fabric samples were lower than both in water and moist ones. In those applications, the highest Berger value was achieved as 43.4 Berger. The results were thought to be concluded from the low penetration of the ozone gas on the dry fabric surface. Similar with the ozone applications to the moist samples, the way of ozone feeding was also not important for dry ones. Therefore, it could be said that the feeding method of ozone gas was not important for the ozone applications in the air.

\subsection{ANOVA results}

After whole applications, statistical analysis was carried out by using Berger results of the fabric samples as outputs. Codes given to the input parameters (given in the Table 2) were showed in Table 3. The results of the established model were given in Table 4 .

Table 3. The inputs for ANOVA

\begin{tabular}{|c|c|c|c|}
\hline $\begin{array}{c}\text { Parameter A: } \\
\text { Ozonation condition }\end{array}$ & $\begin{array}{c}\text { Parameter B: } \\
\text { Number of the passage }\end{array}$ & $\begin{array}{c}\text { Parameter C: } \\
\text { Method of ozone feeding }\end{array}$ & $\begin{array}{l}\text { Parameter D: } \\
\text { Rinsing process }\end{array}$ \\
\hline \multirow{8}{*}{$\begin{array}{l}\text { - In water } \\
\text { - In the air to the moist } \\
\text { sample } \\
\text { - In the air to the dry } \\
\text { sample }\end{array}$} & -50 & -M1 & \multirow{8}{*}{$\begin{array}{l}\text {-Present } \\
\text {-Absent }\end{array}$} \\
\hline & -60 & $-\mathrm{M} 2$ & \\
\hline & -70 & -M3 & \\
\hline & -80 & -M4 & \\
\hline & -90 & -M5 & \\
\hline & -100 & -M6 & \\
\hline & -110 & -M7 & \\
\hline & -120 & -M8 & \\
\hline
\end{tabular}


Table 4. ANOVA results

\begin{tabular}{ccccl}
\hline \multicolumn{2}{c}{ Parameter } & F value & p value & State \\
\hline & Model & 102,3114 & $<0,0001$ & Significant \\
\hline A & & 2964,626 & $<0,0001$ & Significant \\
B & Main factors & 621,8602 & $<0,0001$ & Significant \\
C & & 601,2135 & $<0,0001$ & Significant \\
D & & 55,34082 & $<0,0001$ & Significant \\
\hline AB & & 43,76634 & $<0,0001$ & Significant \\
AC & & 258,9987 & $<0,0001$ & Significant \\
AD & \multirow{2}{*}{ Interactions } & 360,0317 & $<0,0001$ & Significant \\
BC & & 3,785274 & $<0,0001$ & Significant \\
CD & & 6,331554 & $<0,0001$ & Significant \\
ABC & & 5,485473 & $<0,0001$ & Significant \\
\hline
\end{tabular}

The $\mathrm{R}^{2}$ of this analysis was calculated as 0.99 and it was possible to say that the established model was significant. According to Table 4, it could be said that both investigated main factors and double interactions of them had effect on the output. The effect of main factors on the results could be prioritized as the ozonation condition, number of the passage, capacity of the ozone gas, and way of feeding, respectively. The rinsing process had also effect on the results, but its individual contribution was quite low. When the interactions were investigated in detail, it was seen that the most effective one was "AD" interaction. Thus, it was possible to say that while rinsing process had low effect on the whiteness degrees of the fabric samples, individually, it was quite efficient depending on the ozonation conditions. The result could be explained by the ozone residual on the samples depending on the ozonation conditions.

Normal probability diagnostic of the analysis can be seen in Figure 16. The normal probability indicates whether the residuals follow a normal distribution, in which the points will follow a straight line. This plot consists of the number of standard deviations of the actual values from their respective predicted values. Ideally, it should be straight line, indicating no abnormalities [15]. According to Figure 16 , it could be said that there was no problem on any plots and it was also good signal for reliability of the experimental results.

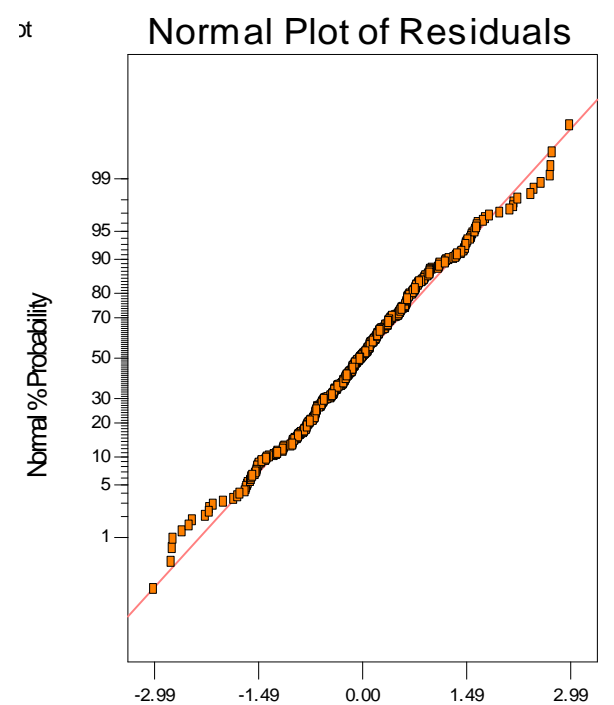

Studentized Residuals

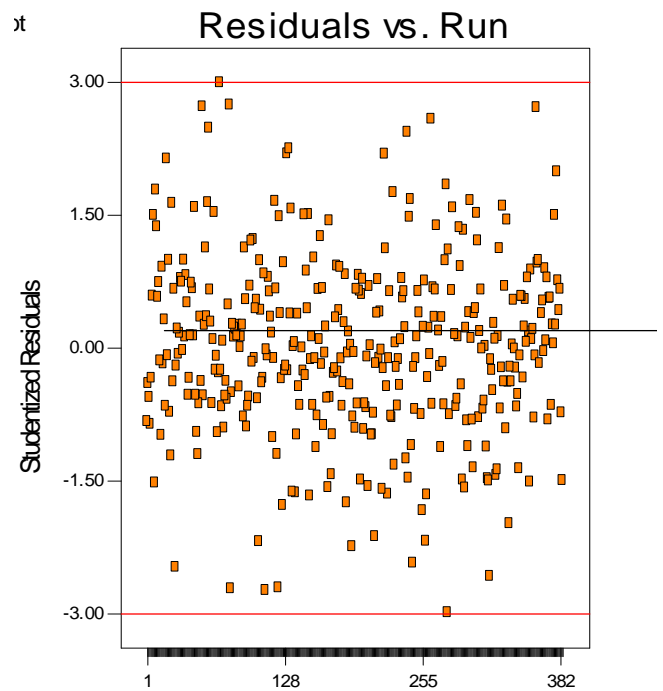

Run Number

Figure 16. The normal probability diagnostic of the analysis 


\section{CONCLUSION}

In this study, usability of the ozone gas at the jigger wet process machine as bleaching material and the effects of the ozonation parameters on the whiteness degrees of $100 \%$ cotton woven fabrics were investigated. For this purpose, effects of ozone bleaching on the whiteness degrees of fabric samples in terms of ozonation condition, ozonation time, production capacity of the ozone gas, and method of ozone feeding were researched. The ozonation conditions were determined as in the water and in the air (moist and dry fabrics). The production capacity of the ozone gas was chosen as $6 \mathrm{~g} / \mathrm{h}, 12 \mathrm{~g} / \mathrm{h}$, and $18 \mathrm{~g} / \mathrm{h}$ while the ozone gas was fed through either rubber diffuser or stone diffuser to the jigger. In addition, ozone applications with the capacity of $18 \mathrm{~g} / \mathrm{h}$ were applied by using both stone diffuser and rubber diffuser. After the ozonation processes, Berger values of the fabric samples after and before rinsing process were measured and the results were compared with the result of conventional hydrogen peroxide bleaching (reference bleaching). The results could be summarized as followings.

- Ozone bleaching process could be applied at the jigger machine.

- Berger values of the samples bleached with ozone gas were measured lower than conventional bleaching.

-Increment in the ozonation time and production capacity of the ozone gas were approached Berger values of the samples to the reference bleaching.

- Highest whiteness results were obtained for ozone applications in the water while the lowest ones were for ozone conditions in the air to the dry fabrics. The result could be explained by not being able to penetrate the ozone gas on the dry fabric surface.

- Way of ozone feeding was crucial for the ozone applications in the water while it was not important for ozone applications in the air. At the applications in the water, the method of feeding of ozone gas affected the results because of the effects on solubility of the ozone gas, and size and homogeneity of the ozone bubbles. Generally, higher Berger values measured for the applications with rubber diffuser than stone one which result was probably concluded from position of the diffusers.

- When the results of applications with different combinations of ozone capacity of $6 \mathrm{~g} / \mathrm{h}$ and $12 \mathrm{~g} / \mathrm{h}$ were focused, it could be said that Berger results of the applications with ozone capacity of $18 \mathrm{~g} / \mathrm{h}$ by using single diffuser was higher.

- Effect of rinsing process differed depending on the ozonation conditions. It had positive effect on the results of the samples for ozone applications in the air.

- According to ANOVA results, all of the investigated main factors had effects on Berger results, statistically. While the most effective main factor on the results was ozonation condition, the lowest one was rinsing process. However, individual effect of rinsing process on the result was low, its double interaction with ozonation condition was quite important. That could be clarified by the ozone residual on the fabric samples depending on the ozonation conditions.

As a conclusion, it is possible to use ozone gas in the jigger machine as a bleaching material and it can be reached conventional bleaching results through appropriate working conditions. If it is wanted to achieve high whiteness effect, applications should be carried out in the water with high ozone capacity (18 g/h) and ozonation time (120 passage) via using rubber diffuser. This study should be enhanced by measuring ozone concentrations in the reaction tank via probe measuring in the water and air.

\section{ACKNOWLEDGEMENT}

This work was supported by the Ministry of Science, Industry and Technology, project number: 01426. STZ. 2012-1. The authors would like to thank the Ministry for its financial support.

\section{REFERENCES}

1. Gülümser, T., Akça, C., \& Bahtiyari, M.İ., (2009). Investigation of the Effects of Ozone on Whiteness Degree in Wool Finishing. Textile and Apparel 1, 52-55.

2. Sancar Beşen, B., (2012). Improving of Sustainable, Economic and Innovative Processes with Ozone Applications for Textile Finishing. (Master's Thesis). Kahramanmaraş Sütçü İmam University, Graduate School of Natural and Applied Sciences, Kahramanmaraş.

3. Hussain, T. \& Wahab, A., (2018). A Critical Review of the Current Water Conservation Practices in Textile Wet Processing, Journal of Cleaner Production, 198, 806-819.

4. Eren, H.A. \& Eren, S., (2017). Ozone Bleaching of Cellulose, IOP Conference Series: Materials Science and Engineering, 254(8), 1-3.

5. Körlü, A., (2018). Use of Ozone in the Textile Industry. Textile Industry and Environment, DOI: http://dx.doi.org/10.5772/ intechopen.81774.

6. Kaşıkara Pazarlığlu, N., Sarışık, M., \&Telefoncu, A., (2005). Laccase: Production by Trametes Versicolor and Application to Denim Washing. Process Biochemistry 40, 1673-1678.

7. Perincek, S., Duran K., Körlü Ekmekçi, A., \&Bahtiyari, İ., (2007). An Investigation in the Use of Ozone Gas in the Bleaching of Cotton Fabrics. Ozone: Science \&Engineering 29(5), 325-333.

8. Arooj, F., Ahmed, N. \& Shaikh, I.A., (2019). Application of Ozone in Stripping of Cotton Fabric Dyed with Reactive Dyes, Ozone: Science \& Engineering, DOI:10.1080/01919512.2019.1667750

9. Turhan, Y., Soydaş, Ş., (2018). The Effects of Ozone Bleaching and Ozone Desizing Method on Whiteness and Water Absorption of $100 \%$ Cotton Terry Fabrics. International Journal of Materials Science and Applications, 7(3), 85-94. 
10. Maqsood, H.S., Bashir, U., Wiener, J., Puchalski, M., Sztajnowski, S. \& Militky, J., (2017). Ozone Treatment of Jute Fibers, Cellulose, 24(3), 1543-1553.

11. Erdem, A. \& İbrahim Bahtiyari, M., (2018). Ultrasonic-Bioscouring and Ozone Based Bleaching of Cotton Slivers and Coloration of them with Natural Dye Sources, Journal of Cleaner Production, 188, 670677.

12. Benli, H. \& Bahtiyari, M.I., (2015). Combination of Ozone and Ultrasound in Pretreatment of Cotton Fabrics Prior to Natural Dyeing, Journal of Cleaner Production, 89, 116-124.

13. Dereli Perincek, S., (2006). An Investigation on the Applicability of Ultrasound, Ultraviolet, Ozone, and Combination of These Technologies as a Pretreatment Process. (Master's Thesis). Ege University, Graduate School of Natural and Applied Sciences, İzmir.

14. Hsu Y, Chen J-T, Yang H., \&Chen J-T., (2001). Decolorization of dyes using ozone in a gas-induced reactor. AIChe Journal 47(1), 169176.

15. Sancar, B., \& Balc1, O., (2013). Decolorization of Different Reactive Dye Wastewaters by $\mathrm{O}_{3}$ And $\mathrm{O}_{3} /$ Ultrasound Alternatives Depending on Different Working Parameters. Textile Research Journal 83(6), $574-590$.

16. Perincek, S., Bahtiyari, İ., Ekmekçi Körlü, A., \&Duran, K., (2009) New Techniques in Cotton Finishing. Textile Research Journal, 79(2), 121-128.

17. Öztürk, D. \&Eren, H.A., (2010). The Use of Ozone in Textile Finishing. Journal of Uludağ University Faculty of Engineering and Architecture, 15(2), 37-51.

18. Sancar Beșen, B., and Balcı, O., (2016). Fading of Cotton Colored with C.I. Vat Blue I (Indigo Dye) via Ozone Application. Ozone:Science\&Engineering 38(5), 395-409.
19. Perincek, S., Duran, K., \&Korlu, A.E., (2013). Combination of Ozonation and Hydrogen Peroxide Bleaching for Linen Fabrics: Optimization of the Process Using Experimental Design Technique, Ozone Science \&Engineering. 35, 316-327.

20. Paksoy, N., (2014). The Applicability of the Pretreatment and Dyeing Processes at Jigger Machine by Using Ozone Gas.(Master's Thesis). Kahramanmaraş Sütçü İmam University, Graduate School of Natural and Applied Sciences, Kahramanmaraş.

21. Xu, P., Janex, M., Savoye, P., Cockx, A., \&Lazarova, V., (2002). Wastewater Disinfection by Ozone: Main Parameters for Process Design, Water Research. 36, 1043-1055.

22. Cardoso, J. C., Bessegato, G. G.\& Zanoni, M. V. B., (2016). Efficiency Comparison of Ozonation, Photolysis, Photocatalysis and Photoelectrocatalysis Methods in Real Textile Wastewater Decolorization, Water Research. 98, 39-46

23. Prabaharan, M.,\&Rao, J., V., (2001). Study On Ozone Bleaching of Cotton Fabric -Process Optimization, Dyeing and Finishing Properties, Coloration Technology. 117, 93-103

24. Bahtiyari, M.I \& Benli, H., (2016). Ozone bleaching of cotton fabrics with the aid of ultrasonic humidifier, Cellulose. 23, 2715-2725

25. Eren, S. \& Yetişir, İ., (2018). Ozone bleaching of woven cotton fabric, Pamukkale Univ Muh Bilim Derg, 24(7), 1245-1248.

26. Hareem, T., Arooj, F., Kashif, S.R. \& Zubair Farooq, (2019). Economic Viability of Pilot-Scale Application of Ozone in Cotton Bleaching with Multiple Reuse of Water, Ozone: Science \& Engineering, 41(2), 197-203 